\title{
IN HOUSE TRAINING PADA PERAWAT PK I - IV TERHADAP PENGETAHUAN TENTANG PLEBITIS DALAM MELAKUKAN SOP PEMASANGAN TERAPI INTRAVENA DI RUMAH SAKIT ADVENT BANDAR LAMPUNG
}

\author{
IN HOUSE TRAINING ON CLINICAL NURSES I-IV TO KNOWLEDGE OF \\ PLEBITIS OF INTRAVENOUS THERAPY AT BANDAR LAMPUNG \\ ADVENTIST HOSPITAL
}

\author{
Ernawaty Siagian ${ }^{1}$, Elia Nopi Kristanto ${ }^{2}$ \\ Fakultas Ilmu Keperawatan, Universitas Advent Indonesia \\ E-mail: ernawatysiagian74@yahoo.com
}

\begin{abstract}
Abstrak
Pendahuluan: Angka kejadian plebitis di Rumah Sakit setiap tahunnya terus meningkat. Dimana angka kejadian ini menjadikan salah satu indikator pelayanan berkualitas di Rumah Sakit. Faktor yang menyebabkan terjadinya plebitis adalah mekanik dan bakteri. Pengetahuan perawat dalam mencegah plebitis sangat penting untuk menurunkan angka kejadian plebitis. Tujuan: Penelitian ini bertujuan untuk mengetahui hubungan tingkat pengetahuan perawat PK I - IV tentang terapi intravena dengan perilaku pencegahan plebitis (mekanik dan bakteria). Metode: Metode yang digunakan pada penelitian ini adalah Expalanatory dengan pendekatan Pre - Eksperimental One-Group Pretest - Post test desain. Dengan tehnik accidental sampling random total accidental dengan melibatkan 89 perawat. Instrumen yang digunakan adalah kuesioner Pre Test dan Post Test in House Training Terhadap Perawat PK I IV Tentang Plebitis Di Rumah Sakit Advent Bandar Lampung. Data dianalisis menggunakan Paired T-Test. Hasil: Tingkat pengetahuan PK I tentang plebitis sebelum seminar adalah $2,79(46,4 \%)$ (pengetahuan sangat kurang) dan setelah seminar $3,57(59,5 \%)$ (pengetahuan hampir cukup). Tingkat pengetahuan perawat PK II tentang plebitis sebelum diberikan seminar 3,35 $(54,16 \%)$ (pengetahuan hampir cukup) dan setelah diberikan seminar 3,75 $(62,5 \%)$ (pengetahuan cukup). Tingkat pengetahuan perawat PK III tentang plebitis sebelum seminar $2,30(38,33 \%)$ (pengetahuan hampir cukup) dan setelah seminar 3,93 (65,5\%) (pengetahuan cukup). Tingkat pengetahuan perawat PK IV tentang plebitis sebelum seminar 2,89 (48,24\%) (pengetahuan kurang) dan setelah 4,16(69,29 \%) (pengetahuan lebih dari cukup). Dalam penelitian ini di dapatkan perbedaan signifikan pada hasil rata-rata nilai pengetahuan perawat PK I - IV sebelum dan sesudah in house training tentang plebitis. Diskusi: Hal ini menggambarkan bahwa in house training merupakan kegiatan yang dapat mempengaruhi tingkat pengetahuan.
\end{abstract}

Kata Kunci: Plebitis, tingkat pengetahuan, mekanik, bakteri

\begin{abstract}
Introduction: The incidence rate of Phlebitis in hospitals every year are increase. Where the incidence rate makes one of the indicators of quality service in the hospital. Therefore, the knowledge of nurses in preventing phlebitis is important to reduce the incidence of phlebitis. Purpose: This study aims to determine the relationship of knowledge level of nurse CN I-IV about intravenous therapy with behavior of prevention of phlebitis (mechanical and bacteria). Method: Equasy Expalanatory Pre - Eksperimental One-Group Pretest - Post test desain research are approaches with sampling random total technique that involving 89 nurses with stratified random sampling technique. The instruments used are pre and post-test in service education questionnaires to the nurses' $\mathrm{CN}$
\end{abstract}

JURNAL

SKOLASTIK

KEPERAWATAN

Vol, 5, No. 1

Januari - Juni 2019

ISSN: $2443-0935$

E-ISSN $2443-16990$ 
I-IV at Bandar Lampung Adventist Hospital, 2018. Results: This data was analyzed using paired T-test. The level of knowledge CN I about phlebitis before the seminar is given the result are 2.79 or $46.4 \%$ (less of knowledge) and after the seminar had given the result are 3,57 or $59,5 \%$ (knowledge is almost enough). The level of knowledge CN II about phlebitis before the seminar is given the result are 3.35 or $54.16 \%$ (the knowledge is almost enough) and after the seminar had given the result are 3.75 or $62.5 \%$ (enough of knowledge). Level of knowledge CN III about phlebitis before the seminar is given the result are 2,30 or $38,33 \%$ (knowledge is almost enough) and after the seminar had given the result are 3,93 or 65, 5\% (knowledge is enough). For the Level of knowledge CN IV about phlebitis before the seminar is given the result are 3,93 or 65, 5\% (knowledge is more than enough) and after the seminar had given the result are 4,21 or $67,7 \%$ (knowledge is more than enough). Discussion: The result of this study indicate that there is a significant difference in nurse knowledge about plebitis in Bandar Lampung Adventist Hospital.

Keywords: Phlebitis, level of knowledge, mechanics, bacteria.

\section{PENDAHULUAN}

Terapi intravena merupakan tindakan yang paling sering dilakukan pada pasien yang menjalani rawat inap sebagai jalur terapi intravena, pemberian obat, cairan, dan pemberian produk darah, atau sampling darah (Alexander, Corigan, Gorski, Hankins \& Perucca, 2010). Infus cairan intravena (intravenous fluids infusion) adalah pemberian sejumlah cairan ke dalam tubuh, melalui sebuah jarum, kedalam pembuluh vena (pembuluh balik) untuk menggantikan kehilangan cairan atau zat-zat makanan dari tubuh (Astaqauliyah, 2011).

Pemberian terapi intravena secara terus menerus dan dalam jangka waktu yang lama akan meningkatkan kemungkinan terjadinya komplikasi dari pemasangan infus, salah satunya adalah plebitis. Plebitis merupakan inflamasi vena yang disebabkan oleh kimia, mekanik dan bakteri. Hal ini, ditunjukkan dengan adanya daerah yang merah, nyeri dan pembengkakan didaerah penusukan atau sepanjang vena (Brunner dan Suddart, 2010: 290).
Menurut Infusion Nursing Society (2006) plebitis merupakan peradangan pada tunika intima pembuluh darah vena, yang sering dilaporkan sebagai komplikasi pemberian terapi infus. Peradangan didapatkan dari mekanisme iritasi yang terjadi pada endhothelium tunika intima vena, dan perlekatan trombosit pada area tersebut (Rohani \& Setio, 2010: 66).

Penelitian Uslusoy (2008), kejadian plebitis akibat pemasangan infus mencapai $41,8 \%$, hal ini sesuai dengan data dari Kemenkes (2011). Infeksi nosokomial terus meningkat $1 \%$ dari beberapa negara di Eropa, Amerika bahkan di Asia, di Amerika latin dan Afrika infeksi nasokomial mengalami peningkatan 40\%. Angka kejadian plebitis di RSUD Indramayu masih di atas standar INS. Sementara kejadian plebitis yang dilaporkan tersebut adalah plebitis sudah tahap lanjut (Wayunah, 2011). Angka kejadian plebitis yang direkomendasikan oleh Infusions Nurses Society adalah 5\%. Jumlah kejadian plebitis menurut distribusi penyakit sistem 
sirkulasi darah pasien rawat inap, Indonesia Tahun 2010 berjumlah 744 orang 17,11\% (Depkes, RI, 2008). Sedangkan dari hasil penelitian Gayatri dan Handiyani (2008) menemukan angka kejadian plebitis di tiga rumah sakit di Jakarta sangat tinggi yaitu $33,8 \%$.

Penyebab plebitis yang paling sering adalah ketidaksesuaian ukuran kateter intravena dan pemilihan lokasi vena, jenis cairan infus, kurangnya tehnik aseptik saat pemasangan, dan waktu kanulisasi yang lama (Hankins, et al., 2001: Richardson \& Bruso, 1993 Gabriel, 2008; Alexander, et al., 2010). Ketidaksesuaian ukuran kateter berhubungan dengan plebitis. Dimana ukuran kateter intravena dipilih sesuai dengan ukuran vena, dan difiksasi dengan baik. Penggunaan kateter intravena yang besar pada vena yang kecil dapat mengiritasi dinding vena (The Center for Disease Control and refentioan (CDC, 2012)).

Upaya yang dapat dilakukan perawat untuk mencegah terjadinya plebitis dengan mengajarkan pasien untuk menjaga sistem infus, seperti menghindari tarikan atau regangan pada selang. Selain itu upaya yang dapat dilakukan perawat untuk mencegah terjadinya plebitis adalah melakukan tehnik aseptik saat pemasangan infus dan saat memberikan obat melalui selang seperti perawat cuci tangan dan menggunakan cairan antiseptik, sebelum melakukan tindakan yaitu untuk mempertahankan tehnik sterilitas sistem infus seperti contoh saat perawat mengganti selang, larutan dan balutan (Perry \& Potter, 2005).
Salah satu parameter yang penting pada mutu pelayanan rumah sakit adalah terkendalinya infeksi. Perawat profesional yang bertugas di Rumah Sakit semakin hari semakin diakui eksistensinya dalam setiap tatanan pelayanan sehingga dalam melakukan tindakan interdependent tak terlepas dari tindakan prosedural yang bersifat invasif tersebut. Tindakan pemasangan infus akan berkualitas apabila dalam pelaksanaannya selalu patuh pada standar prosedur operasional yang telah ditetapkan demi terciptanya pelayanan kesehatan yang bermutu (Notoatmodjo, 2010:127).

Oleh karena itu, dalam melakukan tugasnya tersebut, perawat harus memiliki pengetahuan yang berkaitan dengan pengkajian, perencanaan, implementasi, dan evaluasi dalam perawatan terapi infus. Perawat harus memiliki komitmen dalam memberikan terapi infus yang aman, efektif dalam pembiayaan, serta melakukan perawatan infus yang berkualitas (Alexander, et al., 2010). Perawat berpendapat pemasangan infus adalah hal yang sudah biasa dikerjakan Bahkan ketika ditanya masalah Standar Operasional Prosedur (SOP) pemasangan infus, perawat sedikit mengetahui isi dari SOP tersebut dan ketika diobservasi saat melakukan pemasangan infus ternyata ada beberapa aspek tidak dilakukan yang sesuai dengan isi SOP.

\section{METODE}

Metode yang digunakan pada penelitian ini adalah Expalanatory dengan pendekatan Pre - Eksperimental One-Group Pre test - Post test desain. 
Tehnik accidental sampling random total. Pada desain ini terdapat pre test, sebelum diberikan perlakuan (in house training). Dengan demikian hasil perlakuan dapat diketahui lebih akurat, karena dapat membandingkan dengan keadaan sebelum diberi perlakuan. Dikatakan explanatory karena metode penelitian ini bermaksud menjelaskan kedudukan variabel-variabel yang diteliti serta pengaruh antara satu variabel dengan variabel yang lain. Berdasarkan jenis penelitian tingkat penjelasan, maka tipe penelitian ini adalah penelitian asosiatif (Sugiyono, 2013:74). Alur dari penelitian ini adalah perawat yang digunakan dalam penelitian diberikan pre test (O1) sebelum perlakuan, dilanjutkan dengan pemberian treatment / perlakuan (X) in house training, dan dilanjutkan pemberian perlakuan $(\mathrm{O} 2)$ post test.

Populasi yang digunakan dalam penelitian ini adalah keseluruhan jumlah perawat di Rumah Sakit Advent Bandar Lampung yang berjumlah 183 orang baik perawat klinis PK I - IV. Oleh sebab itu maka akan dipilih beberapa sampel dari populasi yang ada. Nursalam (2008: 93) menyatakan sampel adalah sebagian dari jumlah populasiyang mempunyai karakteristik mirip atau sama dengan populasi sehingga dapat mewakili populasi yang ada. Sedangkan sebagian yang diambil dari keseluruhan objek yang akan diteliti dan mewakili seluruh populasi disebut "sampel penelitian" (Notoadmodjo, 2010). Sugiyono (2007:62) menjelaskan bahwa sampel adalah sebagian dari jumlah dan karakteristik yang dimiliki populasi.
Sampel yang digunakan dalam penelitian ini adalah 89 orang perawat (responden). Tehnik sampling yang digunakan dalam penelitian ini adalah accidental sampling. Nursalam (2003:90) mengatakan accidental samping adalah suatu tehnik penetapan sampel dengan cara memilih sampel diantara populasi yang kebetulan ada sehingga sampel tersebut dapat mewakili populasi lain. Dengan kriteria perawat yang berpengalaman kerja minimal 1 tahun dengan usia 25 35 tahun dan berpendidikan D3 perawat dan S1 Ners di Rumah Sakit Advent Bandar Lampung. Jenjang karir perawat klinis PK I - IV.

\section{HASIL DAN PEMBAHASAN}

\section{Analisa dan Interpretasi Data}

Untuk memperoleh hasil dalam penelitian, maka data yang diperoleh dari jawaban responden berdasarkan kuesioner dianalisis secara deskriptif. Pada bagian ini dibahas mengenai analisa dan interpretasi data yang telah dikumpulkan. Kemudian diolah untuk menjawab tiga pertanyaan yang terdapat pada identifikasi masalah. Data yang dikumpulkan selanjutnya di interpretasikan menurut Tabel 1

Tabel 1 Nilai Rata-Rata Pre Test dan Post Test Tingkat Pengetahuan Perawat PK I - IV dalam In House Training Terapi Intravena dan Plebitis 


\begin{tabular}{lccccc}
\hline \multirow{2}{*}{$\begin{array}{c}\text { Perawat } \\
\text { Klinis }\end{array}$} & Responden & \multicolumn{2}{c}{ Pre - Test } & \multicolumn{2}{c}{ Post - Test } \\
\cline { 2 - 6 } & & Frekuensi & Persentase & Frekuensi & Persentase \\
\hline PK I & 28 & 78 & $46,42 \%$ & 100 & $59,52 \%$ \\
\hline PK II & 12 & 39 & $54,16 \%$ & 45 & $62,50 \%$ \\
\hline PK III & 30 & 69 & $38,33 \%$ & 118 & $65,50 \%$ \\
\hline PK IV & 19 & 55 & $48,24 \%$ & 79 & $69,29 \%$ \\
\hline Total & $\mathbf{8 9}$ & $\mathbf{2 4 1}$ & $\mathbf{4 5 , 1 3 \%}$ & $\mathbf{3 4 2}$ & $\mathbf{6 4 , 0 4 \%}$ \\
\hline
\end{tabular}

Identifikasi Masalah Pertama: Bagaimana gambaran pengetahuan perawat PK I - IV sebelum diberikan intervensi in house training mengenai plebitis?

Untuk menjawab identifikasi masalah pertama, yaitu: "Bagaimana gambaran pengetahuan perawat PK I - IV sebelum diberikan intervensi in house training mengenai plebitis?" maka diberikan kuesioner kepada perawat PK I - IV dan di hitung menggunakan software SPSS dengan rumus mean. Hasil dari perhitungan dapat dilihat pada Tabel 1.

\section{Analisa Data Pre Test PK I}

Berdasarkan analisa dengan menggunakan Tabel 1 dapat diketahui bahwa nilai rata-rata Pre Test tingkat pengetahuan PK I tentang plebitis sebelum in house training diberikan adalah $46,42 \%$

\section{Interpretasi Data Pre Test PK I}

Berdasarkan analisa di atas serta Tabel 1 dapat disimpulkan bahwa nilai ratarata Pre Test PK I tingkat pengetahuan tentang plebitis adalah $46,4 \%$ dalam interprestasi pengetahuan sangat kurang bagi perawat PK I. Dikarenakan perawat masih baru untuk berkecimpung di lapangan kerja dalam arti kurang berpengalaman. Sehingga menyebabkan pengetahuan sangat kurang.

Plebitis disebabkan oleh banyak faktor. Penyebab yang paling sering adalah ketidaksesuasian ukuran kateter dan pemilihan lokasi vena, jenis cairan, kurang aseptik saat pemasangan, dan kanulisasi yang lama (Hanskin, et al, 2001; Richardson \& Bruso, 1993; dalam Gabriel, 2008; Alexander, et al., 2010)

\section{Analisa Data Pre Test PK II}

Berdasarkan analisa dengan menggunakan Tabel 1 dapat disimpulkan bahwa nilai rata-rata Pre Test tingkat pengetahuan PK II tentang plebitis sebelum seminar diberikan adalah 54,16\% 4.2.1.4 Interpretasi Data Pre Test PK II. Berdasarkan analisa di atas serta Tabel 1 dapat disimpulkan bahwa nilai rata-rata Pre Test PK II tingkat pengetahuan tentang plebitis adalah 54,16\% dalam interprestasi pengetahuan hampir cukup bagi perawat PK II. Pengetahuan adalah sesuatu yang diketahui berkaitan dengan proses pembelajaran. Proses ini dipengaruhi dari dalam, seperti motivasi dan faktor luar berupa sarana 
informasi yang tersedia, serta keadaan sosial budaya. Pengetahuan adalah informasi atau maklumat yang diketahui atau disadari oleh seseorang (Agus, 2013).

\section{Analisa Data Pre Test PK III}

Berdasarkan analisa dengan menggunakan Tabel 1 dapat disimpulkan bahwa nilai rata-rata Pre Test tingkat pengetahuan PK III tentang plebitis sebelum in house training diberikan adalah $38,33 \%$.

\section{Interpretasi Data Pre Test PK III}

Berdasarkan analisa di atas serta Tabel 1 dapat disimpulkan bahwa nilai ratarata Pre Test PK III tingkat pengetahuan tentang plebitis adalah $38,33 \%$ dalam interprestasi pengetahuan hampir cukup bagi perawat PK III. Informasi yang diperoleh baik dari pendidikan formal maupun non formal dapat memberikan pengaruh jangka pendek (immediate impact) sehingga menghasilkan perubahan atau peningkatan pengetahuan. Majunya teknologi akan tersedia bermacam-macam media massa yang dapat mempengaruhi pengetahuan masyarakat tentang inovasi baru. Sebagai sarana komunikasi, berbagai bentuk media massa seperti televisi, radio, surat, kabar, majalah, dan lain-lain mempuyai pengaruh besar terhadap pembentukan opini dan kepercayaan orang.

Analisa Data Pre Test PK IV
Berdasarkan analisa dengan
menggunakan Tabel 1 dapat
disimpulkan bahwa nilai rata-rata Pre
Test tingkat pengetahuan PK IV
tentang plebitis sebelum in house
training diberikan adalah 48,24\%

\section{Interpretasi Data Pre Test PK IV}

Berdasarkan analisa di atas serta Tabel 1 dapat disimpulkan bahwa nilai ratarata Pre Test PK IV tingkat pengetahuan tentang plebitis adalah 48,24\% dalam interprestasi pengetahuan kurang bagi perawat PK IV. Usia mempengaruhi terhadap gaya tangkap dan pola pikir seseorang. Semakin bertambah usia akan semakin berkembang pula daya tangkap dan pola pikirnya, sehingga pengetahuan yang diperolehnya semakin membaik. Pada usia madya, individu akan lebih berperan aktif dalam masyarakat dan kehidupan sosial serta lebih banyak melakukan persiapan demi suksesnya upaya menyesuaikan diri menuju usia tua, selain itu orang usia madya akan lebih banyak menggunakan banyak waktu untuk membaca.

Identifikasi Masalah Kedua: Bagaimana gambaran pengetahuan perawat PK I - IV sesudah diberikan intervensi in house training mengenai plebitis?

Untuk menjawab identifikasi masalah kedua, yaitu: "Bagaimana gambaran pengetahuan perawat PK I - PK IV sesudah diberikan intervensi in house training mengenai plebitis?" maka diberikan kuesioner kepada perawat PK I - IV dan di hitung menggunakan software SPSS versi 24 dengan rumus mean.

\section{Analisa Data Post Test PK I}

Berdasarkan analisa dengan menggunakan Tabel 1 dapat diketahui bahwa nilai rata-rata Post Test tingkat pengetahuan PK I tentang plebitis sebelum in house training diberikan adalah 59,5 \% 4.2.2.2 Interpretasi Data Post Test PK I. Berdasarkan analisa di 
atas serta Tabel 1 dapat disimpulkan bahwa nilai rata-rata Post Test PK I tingkat pengetahuan tentang plebitis adalah 59,5\% dalam interprestasi pengetahuan hampir cukup bagi perawat PK I. Banyak faktor yang mempengaruhi terjadinya plebitis, diantaranya kepatuhan perawat dalam menerapkan prosedur tindakan sesuai dengan SOP. Kepatuhan merupakan wujud dari suatu tindakan yang sudah menjadi perilaku (Wayunah, Elly Nurachmah, dan Sigit Mulyono, 2011).

\section{Analisa Data Post Test PK II}

Berdasarkan analisa dengan menggunakan Tabel 1 dapat disimpulkan bahwa nilai rata-rata Post Test tingkat pengetahuan PK II tentang plebitis sebelum in house training diberikan adalah $62,5 \%$

\section{Interpretasi Data Post Test PK II}

Berdasarkan analisa di atas serta Tabel 1 dapat disimpulkan bahwa nilai ratarata Post Test PK II tingkat pengetahuan tentang plebitis adalah $62,5 \%$ dalam interprestasi pengetahuan cukup bagi perawat PK II.

Pengetahuan (Knowledge) merupakan hasil dari tahu dan ini terjadi setelah orang melakukan penginderaan terhadap suatu objek tertentu. Penginderaan terjadi melalui panca indera manusia, yakni indera pengelihatan, pendengaran, penciuman, rasa, dan raba. Sebagian pengetahuan manusia diperoleh melalui mata dan telinga. Pada waktu penginderaan sampai menghasilkan pengetahuan tersebut sangat dipengaruhi oleh intesitas perhatian persepsi terhadap obyek. Sebagian besar pengetahuan seseorang diperoleh melalui indera pendengaran yaitu telinga dan indera pengelihatan yaitu mata (Notoadmodjo, 2012).

\section{Analisa Data Post Test PK III}

Berdasarkan analisa dengan menggunakan Tabel 1 dapat disimpulkan bahwa nilai rata-rata Post Test tingkat pengetahuan PK III tentang plebitis sebelum in house traning diberikan adalah 65,5\%

\section{Interpretasi Data Post Test PK III}

Berdasarkan analisa di atas serta Tabel 1 dapat disimpulkan bahwa nilai ratarata Post Test PK III tingkat pengetahuan tentang plebitis adalah $62,5 \%$ dalam interprestasi pengetahuan cukup bagi perawat PK III.

Menurut Notoadmodjo (2011), pengetahuan mengungkapkan bahwa sebelumnya orang mengadopsi perilaku baru didalam arti orang tersebut terjadi proses sebagai berikut:

1) Kesadaran (Awarenes), dimana orang tersebut menyadari dalam arti mengetahui terlebih dahulu terhadap stimulasi (objek).

2) Merasa (Interest), tertarik terhadap stimulasi atau objek tersebut disini sikap objek mulai timbul.

3) Menimbang-nimbang

(Evaluation), terhadap baik dan tidaknya stimulasi tersebut bagi dirinya, hal ini berarti sikap responden sudah lebih baik lagi.

4) Mencoba (Trial), dimana subjek mulai mencoba melakukan sesuatu sesuai dengan apa yang dikehendaki.

5) Adaptasi (Adaptation). Subjek sudah berperilaku baru sesuai dengan pengetahuan, kesadaran, dan sikapnya terhadap stimulus. 


\section{Analisa Data Post Test PK IV}

Berdasarkan analisa dengan menggunakan Tabel 1 dapat disimpulkan bahwa nilai rata-rata Post Test tingkat pengetahuan PK IV tentang plebitis sebelum seminar diberikan adalah 69,29\%.

\section{Interpretasi Data Post Test PK IV}

Berdasarkan analisa di atas serta Tabel 1 dapat disimpulkan bahwa nilai ratarata Post Test PK IV tingkat pengetahuan tentang plebitis adalah $69,29 \%$ dalam interprestasi pengetahuan lebih dari cukup bagi perawat PK IV. Usia mempengaruhi terhadap gaya tangkap dan pola pikir seseorang. Semakin bertambah usia akan semakin berkembang pula daya tangkap dan pola pikirnya, sehingga pengetahuan yang diperolehnya semakin membaik. Pada usia madya, individu akan lebih berperan aktif dalam masyarakat dan kehidupan sosial serta lebih banyak melakukan persiapan demi suksesnya upaya menyesuaikan diri menuju usia tua, selain itu orang usia madya akan lebih banyak menggunakan banyak waktu untuk membaca.

Adakah perbedaan yang signifikan antara pengetahuan perawat sebelum dan sesudah diberikan intervensi seminar mengenai plebitis?

Untuk menjawab identifikasi masalah ketiga, yaitu: “Adakah perbedaan yang signifikan antara pengetahuan perawat sebelum dan sesudah diberikan intervensi seminar mengenai plebitis?" maka dihitung menggunakan software SPSS versi 24.

Tabel 2 Hasil Pengolahan Paired t-test

\begin{tabular}{cccc}
\hline \multicolumn{4}{c}{ Paired Samples Test } \\
\hline \\
Pair 1 & PK I Pre - PK I Post & Sig. (2tailed) & Interprestasi \\
\hline Pair 2 & PK II Pre - PK II Post & 0.010 & Signifikan \\
\hline Pair 3 & PK III Pre - PK III Post & 0.191 & Tidak Signifikan \\
\hline Pair 4 & PK IV Pre - PK IV Post & 0.000 & Signifikan \\
\hline
\end{tabular}

\section{Analisa Data}

Nilai taraf kepercayaan paired sample ttest adalah <0,05. Berdasarkan hasil pada tabel diatas menunjukkan bahwa nilai signifikan untuk PK I p=0,010 <
0,05 oleh karena itu Ho ditolak yang berarti $\mathrm{Ha}$ diterima yaitu adanya perbedaan yang signifikan antara pengetahuan perawat PK I sebelum dan sesudah diberikan intervensi in house 
training mengenai plebitis. Nilai signifikan untuk PK II p=0,191 > 0,05 oleh karena itu Ho diterima yang berarti tidak ada perbedaan yang signifikan antara pengetahuan perawat PK II sebelum dan sesudah diberikan intervensi in house training mengenai plebitis. Nilai signifikan untuk PK III $\mathrm{p}=0,000<0,05$ oleh karena itu Ho ditolak yang berarti Ha diterima yaitu adanya perbedaan yang signifikan antara pengetahuan perawat PK III sebelum dan sesudah diberikan intervensi in house training mengenai plebitis. Nilai signifikan untuk PK IV $\mathrm{p}=0,000<0,05$ oleh karena itu Ho ditolak yang berarti Ha diterima yaitu adanya perbedaan yang signifikan antara pengetahuan perawat PK IV sebelum dan sesudah diberikan intervensi in house training mengenai plebitis.

\section{Interpretasi Data}

Berdasarkan analisa dari identifikasi masalah ketiga bahwa ada perbedaan yang signifikan antara pengetahuan sebelum dan sesudah diberikan in house training pada perawat PK I, III, dan IV. Dan juga menunjukkan tidak ada perbedaan yang signifikan antara pengetahuan sebelum dan sesudah diberikan in house training ada perawat PK II. Hasil analisis menunjukkan cukup bukti untuk menolak Ho dan menerima hipotesis alternative pada perawat PK I, III, dan IV dan hasil analisis juga tidak menunjukkan cukup bukti untuk menolak Ho pada perawat PK II. Pengetahuan perawat PK I pada awal penelitian didapati dalam tingkat pengetahuan sangat kurang, pengetahuan perawat PK II pada awal penelitian didapati dalam tingkat pengetahuan hampir cukup, pengetahuan perawat PK III pada awal penelitian didapati dalam tingkat hampir cukup, dan pengetahuan perawat PK IV dalam tingkat kurang. Kemudian setelah diberikan in house training mengenai plebitis didapati pengetahuan perawat PK I dalam tingkat hampir cukup, pengetahuan perawat PK II dalam tingkat cukup, pengetahuan perawat PK III dalam tingkat cukup dan pengetahuan perawat PK IV lebih dari cukup.

\section{Pembahasan Hasil}

Pengetahuan adalah sesuatu yang diketahui berkaitan dengan proses pembelajaran. Proses ini dipengaruhi dari dalam, seperti motivasi dan faktor luar berupa sarana informasi yang tersedia, serta keadaan sosial budaya. Pengetahuan adalah informasi atau maklumat yang diketahui atau disadari oleh seseorang (Agus, 2013).

Hasil penelitian ini menunjukkan adanya peningkatan pengetahuan setelah dilakukan in house training. Dilihat dari nilai rata-rata pre test yang lebih rendah daripada nilai rata-rata post test. Hal ini menunjukkan bahwa in house training memiliki peran dalam menambah tingkat pengetahuan perawat PK I - IV tentang pengetahuan terhadap plebitis dalam SOP pemasangan terapi intravena di Rumah Sakit Advent Bandar Lampung 2018. Dalam penelitian ini juga di dapatkan perbedaan signifikan pada hasil ratarata nilai pengetahuan perawat PK I IV sebelum dan sesudah in house training tentang cairan dan plebitis. Hal ini menggambarkan bahwa in house training merupakan kegiatan yang dapat mempengaruhi tingkat pengetahuan. 
Menurut Mubarak (2007), menyatakan perilaku yang didasari pengetahuan akan menjadi langgeng dari pada perilaku yang tidak didasari pengetahuan. Pendidikan, umur, pengalaman merupakan faktor-faktor yang dapat mempengaruhi pengetahuan dari seorang perawat yang dapat diambil dari faktorfaktor yang mempengaruhi pengetahuan. Suprapto (2015: 768), menyatakan perawat yang memiliki pengetahuan beik belum tentu memiliki kepatuhan baik pula, ada beberapa faktor yang berpengaruh terhadap tingkat kepatuhan antara lain kemampuan, motivasi, pengetahuan, masa kerja, latar belakang pendidikan, fasilitas atau peralatan, bahan serta kejelasan prosedur.

\section{HASIL}

\section{Kesimpulan}

Setelah diadakan pembahasan maka kesimpulan yang dapat diambil dari penelitian ini adalah sebagai berikut:

1. Tingkat pengetahuan perawat PK I RSABL tentang plebitis sebelum in house training rata-rata adalah 2,79 atau $46,4 \%$ yaitu tingkat pengetahuan sangat kurang, perawat PK II sebelum in house training rata-rata 3,35 atau $54,16 \%$ yaitu tingkat pengetahuan hampir cukup, perawat PK III RSABL sebelum in house training rata-rata adalah 2,30 atau $38,33 \%$ yaitu tingkat pengetahuan hampir cukup, dan perawat PK IV RSABL sebelum in house training ratarata adalah 2,89 atau $48,24 \%$ yaitu tingkat pengetahuan kurang.

2. Tingkat pengetahuan perawat PK I RSABL tentang plebitis sesudah in house training rata-rata adalah 3,57 atau $59,5 \%$ yaitu tingkat pengetahuan hampir cukup, perawat PK II RSABL sesudah in house training rata-rata 3,75 atau $62,5 \%$ yaitu tingkat pengetahuan cukup, perawat PK III RSABL sesudah seminar rata-rata adalah 3,75 atau 62,5 $\%$ tingkat pengetahuan cukup, dan perawat PK IV RSABL sesudah seminar rata-rata adalah 4,16 atau $69,29 \%$ yaitu tingkat pengetahuan lebih dari cukup.

3. Dalam penelitian ini juga di dapatkan perbedaan signifikan pada hasil ratarata nilai pengetahuan perawat PK I IV sebelum dan sesudah in house training tentang cairan dan plebitis. Hal ini menggambarkan bahwa in house training merupakan kegiatan yang dapat mempengaruhi tingkat pengetahuan.

\section{Saran}

Adapun saran-saran peneliti sebagai berikut:

1. Pimpinan Keperawatan, untuk dapat menjadi bahan masukan dalam upaya untuk meningkatkan pengetahuan perawat PK I - PK IV guna meningkatkan kualitas pelayanan perawatan di Rumah Sakit Advent Bandar Lampung terutama pada SOP pemasangan terapi intravena sehingga tidak menimbulkan plebitis pada pasien.

2. Perawat, sebagai masukan agar dapat meningkatkan pengetahuan perawat tentang terapi intravena dan plebitis dalam meningkatkan kualitas pelayanan, salah satunya dengan meningkatkan kepatuhan perawat dalam melakukan SOP pemasangan terapi intravena di Rumah Sakit Advent Bandar Lampung.

3. Pendidikan sebagai masukan agar penelitian dapat menjadi bahan masukan dalam kegiatan belajar 
mengajar, dan sebagai bahan ajar untuk memperkaya wawasan bagi mahasiswa khususnya mahasiswa ilmu keperawatan.

4. Penelitian, sebagai masukan agar diharapkan hasil penelitian ini dapat menjadi data dasar untuk dikembangkan dalam penelitian selanjutnya dengan

Pendekatan

\section{DAFTAR PUSTAKA}

Alexander, M., Corrigan, A., Gorski, L., Hankins, J., \&Perucca, R. (2010). Infusion nursing: An evidence based approach,3nd ed. St. Louis: Saunders Elsevier.

Arikunto, S. (2010). ProsedurPenelitian: Suatu Pendekatan Praktik. Jakarta: Rineka Cipta.

Arikunto, Suharsimi. (2007). DasarDasar Evaluasi Pendidikan, Edisi 2, Jakarta: PT. Bumi Aksara.

Basrowi, Soeyono. (2007) Metode Analisis Data Sosial. Kediri: CV. Jenggala Pustaka Utama.

Budiono dan Pertami, B. S., (2015). Konsep Dasar Keperawatan. Jakarta: Bumi Medika.

Divisi KnD Center PT Pratama Indomitra Konsultan (2012) Meningkatkan Kualitas SDM Dengan in House Training. [online]. Available: http://pratamaindomintra.co.id/in -house-training-meningkatkankualitassdm.htm [14 Maret 2018]

\begin{abstract}
Indo Nursing (2016) Soal Ujian Kompetensi Ners dan Pembahansannya. [online]. Available: http://eindonursing.blogspot.com/2016/ 09/contoh-soal-ukniujikompetensi-ners.html [15 Maret 2018] Frisilla, Sefti dan Jill (2016). Hubungan Lama kerja Dengan Kepatuhan Perawat Dalam Melaksanakan SOP Pemasangan Infus Di RSU GMIM Pancaran Kasih Manado, e-jurnal Keperawatan, 4(2), 1-6.
\end{abstract}

Handoko Riwidikdo, S. Kp (2013). Statistik Kesehatan Dengan Aplikasi SPSS dalam Prosedur Penelitian, Yogyakarta: Rohima Press.

Hidayat, A. (2009). Metode penelitian keperawatan dan teknik analisis data. Jakarta: PT. SalembaMedika.

Kozier, B., Erb, G., Berman, A., \&Synder, S.J. (2010). Buku ajar fundamental keperawatan: konsep, proses, dan praktik. (E. Wahyuningsih, D. Yulianti, Y. Yuningsih, \& A. Lusyana, Penerjemah). Jakarta: EGC.

Maria, I., \& Kurnia, E. (2012). Kepatuhan Perawat Dalam Melaksanakan Standar Prosedur Operasional Pemasangan Infus Terhadap Phlebitis. Jurnal STIKES, Volume 5: 39-40.

Mubarak. W (2007). Promosi Kesehatan: sebuah pengantar proses belajar mengajar dalam 
pendidikan, Yogyakarta: Graha Ilmu

Notoatmodjo. (2015). Ilmu Perilaku Kesehatan. Jakarta: RinekaCipta.

Pearce, E.C. (2011). Anatomi Dan Fisiologi Untuk Para Medis. Jakarta: PT. Ikrar Mandiriabadi.

Potter, P. A. \& Perry, A.G. (2009). Fundamental Keperawatan buku 2 edisi 7. (A. Federika, Penerjemah). Jakarta: Salemba Medika.

Prof. Dr. Nursalam, M. Nurs (Hons). (2014). Manajemen Keperawatan: Aplikasi Dalam Praktik Keperawatan Profesional Edisi 4. Jakarta: Salemba Medika.

Prof. Dr. Sugiyono. (2016). Metode Penelitian Kombinasi. Bandung: Penerbit Alfabeta.

PT. Otsuka Indonesia. (2012). Dasar Terapi Cairan dan Nutrisi. Jakarta. Rohani (2015), Hubungan Lama Pemasangan Infus Dengan Terjadinya Plebitis di RS Husada Tahun 2015, Jurnal Ilmiah WIDYA, 3(4), 1-7

Rohani. (2016). Hubungan Lama Pemasangan Infus Dengan Terjadinya Plebitis di RS Husada Jakarta tahun 2015. Jurnal ilmiah WIDYA, 3(4)1-2.

Smeltzer, S.et.al. (2008). Keperawatan Medikal Bedah. Brunner \& Suddarth text book.
Sukardi (2013). Metodologi Penelitian Pendidikan: Kompetensi dan Pratiknya. Jakarta: PT. Bumi Aksara

Sudijono, Anas. (2009). Pengantar Evaluasi Pendidikan. Jakarta: Raja Grafindo

Suprapto (2015). Hubungan Antara Tingkat Pengetahuan Perawat Tentang Pemasangan Infus Dengan Kepatuhan Pelaksanaan Protap Pemasangan Infus di Instalasi Gawat Darurat RS TK II Pelamonia Makassar, JKI, 1(2), 759-769

Terumo Indonesia. (2013). Pemasangan Infus dengan Baik dan Benar. Jakarta.

Wayunah, Nurachmah, E., \& Mulyono, S. (2011). Hubungan Pengetahuan Perawat Tentang Terapi Infus dengan Kejaidian Plebitis dan Kenyamanan Pasien di Ruang Rawat Inap RSUD Indramayu. 16(2) 1-2. 